\title{
Energy Saving and Life Cycle Analysis of a Daylight-Linked Control System
}

\author{
(D) Ceyda Aksoy Tırmıkçı1 ${ }^{1}$, Denk Yavuz ${ }^{2}$ \\ ${ }^{1}$ Corresponding Author; Sakarya University, Eng. Faculty Electrical and Electronics Eng. Dept., \\ Esentepe Campus, 54187, Serdivan, Sakarya, Turkey; caksoy@sakarya.edu.tr; +90 2642955632 \\ ${ }^{2}$ Sakarya University, Eng. Faculty Electrical and Electronics Eng. Dept., Esentepe Campus, 54187, Serdivan, \\ Sakarya, Turkey; cyavuz@sakarya.edu.tr
}

Received 24 July 2020; Revised 5 October 2020; Accepted 5 October 2020; Published online 30 December 2020

\begin{abstract}
The main purpose of this work is to examine the environmental impact of a daylight-linked dimming lighting control system integrated in the Lighting Laboratory of Electrical and Electronics Engineering Department, Sakarya University. For this purpose, total annual energy savings and greenhouse gas emission savings is performed in terms of measured annual in operation data and calculated life cycle energy data. The results indicate that the system provides 1,519.55 kWh annual energy savings and spends $365.26 \mathrm{kWh}$ life cycle energy. Assuming that life time of a lighting control system is ten years, annual energy spent by the control system is estimated $36.54 \mathrm{kWh} /$ year. Total annual lighting energy savings, subtraction of estimated annual life cycle energy from measured annual energy savings, are calculated 1,483.01 kWh which is nearly $40 \%$ of total annual lighting energy consumption of the test room accordingly. In conclusion, it is established that emissions of the test room are reduced $2.71 \mathrm{tCO}_{2}$ annually by the lighting control system proposed in this work.
\end{abstract}

Keywords: daylight-adaptive systems, dimmable electronic ballasts, life cycle analysis, energy savings, greenhouse gas emission savings, climate change

\section{Introduction}

It is a fact that anthropogenic greenhouse gas emissions which have been proceeding at an unprecented rate since 1880 induced the past century's warming at a critical level between $0.8^{\circ} \mathrm{C}$ and $1.2^{\circ} \mathrm{C}$ [IPCC]. Today, the effects of this rising warming trend are noticeable indisputably in natural and human systems as heatwaves, frost free seasons, rising sea levels, wildfires, floods, droughts and a range of others. According to the climate models, it is possible to limit the warming less than $0.5^{\circ} \mathrm{C}$, if all human activity related emissions are reduced to zero. It is vital to limit the warming to $1.5^{\circ} \mathrm{C}$ since risks are increasing dramatically in $2^{\circ} \mathrm{C}$ scenarios [1].

The buildings and building construction sectors have been growing rapidly in the last decade as a result of rising demands of modern world. The reports show that the sectors are responsible for $40 \%$ of total direct and indirect global energy related emissions, the major contributor of anthropogenic emissions [2]. Thus, mitigation of building related emissions is vital for limiting the warming at desired levels.

Artificial lighting makes a significant contribution to total energy consumption in the buildings after heating, air conditioning and ventilation. However, this contribution can be reduced to minimum or even to zero with the use of lighting control systems and LED technologies. Lighting control systems are investigated in three groups: daylight-linked lighting control systems, occupancy-based control schemes and timers [3]. Daylight-linked control systems are used to provide adequate lighting levels in buildings by switching on/off or dimming scenarios [4, 5]. Daylight-linked switching lighting control systems determine the switching on and off ranges of a particular zone between $100 \%$ on and $100 \%$ off conditions based on daylight availability. On the other hand, control systems with dimming scenarios determine the illuminance level of artificial lighting systems by dimmable electronic ballasts in reference to the level of available daylight. Switching based control systems are usually used in outdoor applications or used in indoor applications combined with dimmable electronic ballasts [6]. 
In current literature, there are many studies which investigate the energy savings by daylight-linked control systems. Chung et al. investigated artificial lighting energy savings of a Government building with dimmable electronic ballasts and measured 20\% savings [7]. Guillemin et al. developed a daylight-linked lighting controller for a self-adaptive building and recorded $25 \%$ annual savings in lighting energy consumption [8]. Onaygil et al. integrated a daylight responsive lighting system in a building in İstanbul and saved 31\% in lighting energy [9]. Atif et al. tested the energy performance of two different daylight-linked lighting control systems in two large atrium spaces. They established that dimming lighting control system saved $46 \%$ in lighting energy and switching control system provided 11\%-\%17 lighting energy savings [10]. Li et al. presented an experimental study to investigate the performance of daylight-linked lighting control systems installed in a school building. They recorded 19.8\%-65.5\% fractional lighting energy savings under various control scenarios [Li DHW et al. 2010]. Delvaeye et al. investigated energy savings of three different daylight-linked lighting control systems in a school building and monitored total annual lighting energy savings between $18 \%$ and $46 \%$ [11]. Demirbaş et.al. figured out that up to $45 \%$ of lighting energycan be saved and $11.4 \mathrm{kgCO}_{2} / \mathrm{m}^{2}$ emission can be prevented just designing the offices to have a better daylight penetration and equip the artificial lighting with an automation system [12].

The objective of this study is to investigate the lighting energy saving potential and carbon footprint of a daylight-linked lighting control system integrated in the Lighting Laboratory of Electrical and Electronics Engineering Department, Sakarya University. The lighting control system is a dimming based system which controls lighting levels of 8 double parabolic mirror louver luminaries to provide recommended standard lighting conditions for a laboratory and an office room. The lighting conditions of the laboratory is monitored from 08:30 to 18:30 every day for a year by a data collection unit, Daqpro 5300. The measures for lighting energy savings are used to estimate greenhouse gas emission savings obtained by the laboratory considering the energy consumption for production and use phases of dimmable electronic ballasts of the lighting control system. The results indicate that the lighting control system examined in this work provides 1,483.01 kWh energy savings and $2.71 \mathrm{tCO}_{2}$ emissions savings every year.

\section{Methodology}

The test room, Lighting Laboratory, is a $36 \mathrm{~m}^{2}$ room with one window oriented to the west located at $40^{\circ} 74$ ' North latitude and $30^{\circ} 33^{\prime}$ East longitude. The window of the room has a total area of 4.29 $\mathrm{m}^{2}$ with an optimum height of $2.45 \mathrm{~m}$ [13]. The ceiling of the room is $2.85 \mathrm{~m}$ height and coloured in white with a reflection factor of 0.86 . The walls and the floor are coloured in cream and brown with reflection factors 0.73 and 0.4 respectively. Artificial lighting system of the room are 8 double mirror louver luminaries positioned in three rows which has two fluorescent lamps with $4000 \mathrm{~K}$ of colour temperature and $5200 \mathrm{~lm}$ flux (Figure 1). All luminaries are connected to different dimmable electronic ballasts controlled by Osram DALI Basic RC lighting automation system. Lighting conditions of system are monitored by Daqpro 5300 and energy analysis of the room is performed by Janitza UMG 503. Monthly energy savings in lighting energy consumption of the test room is given in Table 1.

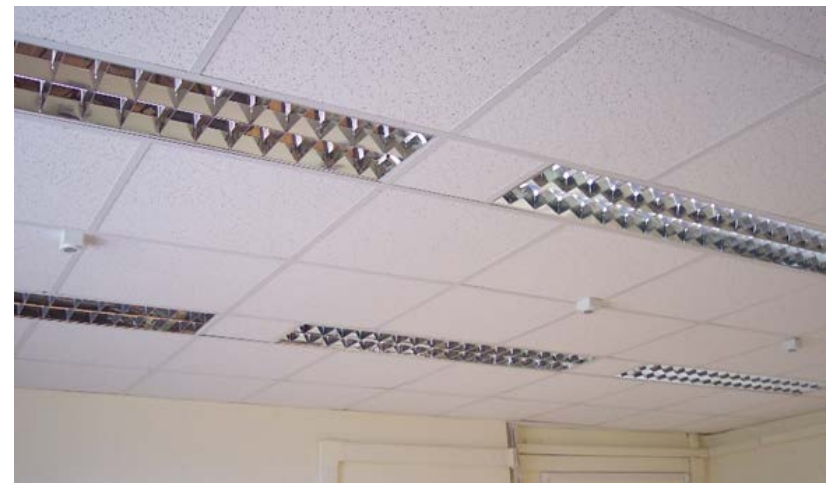

Figure 1 Artificial lighting of the test room 
Aksoy Tırmıkçı et. al

Table 1 Initial Results

\begin{tabular}{|c|c|c|}
\hline Month & Savings (\%) & Savings [kWh] \\
\hline January & 28.6 & 91.32 \\
\hline February & 25.8 & 74.46 \\
\hline March & 41.5 & 132.38 \\
\hline April & 43.7 & 135.12 \\
\hline May & 48.7 & 155.59 \\
\hline June & 61.2 & 189.20 \\
\hline July & 60.1 & 191.80 \\
\hline August & 54.5 & 173.92 \\
\hline September & 39.8 & 123.07 \\
\hline October & 32.4 & 103.29 \\
\hline November & 25.1 & 77.40 \\
\hline December & 22.6 & 72.00 \\
\hline
\end{tabular}

Table 1 shows that daylight-linked dimming control system integrated in the test room provides more than $40 \%$ savings in total annual lighting energy consumption. Literature review and the results of this work support the fact that benefiting from daylight in lighting systems reduces the energy consumption and energy related greenhouse gas emissions. However, electronic ballasts used in lighting control systems also have embodied energy and embodied greenhouse gas emissions due to their life cycle stages; fabrication, transportation, installation and use [14]. Bakri et al. proposed that $45.67 \mathrm{kWh}$ energy is required to produce and use one electronic ballast by using primary energy sources, fossil fuels [15].

\section{Results and Discussion}

Annual energy savings in lighting energy consumption by the control system in this work is measured 1,519.55 kWh (Table 1). Life cycle energy of electronic ballasts of the control system is calculated $365.36 \mathrm{kWh}$. Assuming that life time of an electronic ballast is ten years, embodied energy of the control system is $36.54 \mathrm{kWh} /$ year. Total annual lighting energy savings equals to subtraction of embodied energy of the control system from measured annual energy savings and calculated 1,483.01 kWh accordingly.

Table 2 indicates electricity generation and $\mathrm{CO}_{2}$ emissions by primary energy sources of Turkey in 2018 [16]. According to Table 2, $\mathrm{CO}_{2}$ emission factor, total energy based $\mathrm{CO}_{2}$ emissions divided by total fossil fuel use for electricity generation, is $1.83 \mathrm{tCO}_{2} / \mathrm{MWh}$.

Table 2 Electricity generation and $\mathrm{CO}_{2}$ emissions by primary energy sources of Turkey in 2018

\begin{tabular}{|l|l|l|}
\hline Energy source & Electricity generation [GWh] & $\mathbf{C O}_{2}$ emissions [Mt] \\
\hline Natural Gas & $110,490.0$ & 102.0 \\
\hline Coal & $97,476.0$ & 157.0 \\
\hline Oil & $1,200.0$ & 119.0 \\
\hline
\end{tabular}

Energy and emission calculations show that the lighting control system investigated in this work saves $1,483.01 \mathrm{kWh}$ lighting energy and $2.71 \mathrm{tCO}_{2}$ emissions every year. It is a fact that emission $\mathrm{CO}_{2}$ factors of Turkey has a rising trend in the last decade due to the rapid rise in fossil fuel based energy demands [17]. Therefore, strict measures must be implemented to reduce energy consumption and energy based greenhouse gas emissions to meet the climate change goals. Retrofitting the lighting systems of office rooms and working places with daylight responsive control systems like the system examined in this paper can provide at least $11.03 \mathrm{TWh} /$ year lighting energy savings and 20.2 $\mathrm{MtCO}_{2}$ /year emission savings, assuming that the control system saves $20 \%$ of total lighting energy consumption. However, life cycle stages of electronic ballasts have non-negligible damages on human health, ecosystem quality and resource depletion [15]. Therefore, the modern future world priority must be reducing energy consumption and then investing in advanced technologies for a sustainable future. 


\section{Conclusion}

This work investigates greenhouse gas emission savings by a dimming lighting control system integrated in a laboratory of a public university, taking account of emissions released during the life cycle of system components. Total annual savings by the control system in lighting energy consumption is measured $1,519.55 \mathrm{kWh}$ whereas total life time energy used by dimmable electronic ballasts is estimated $365.36 \mathrm{kWh}$. In conclusion total annual savings in lighting energy consumption and greenhouse gas emissions are calculated $1,483.01 \mathrm{kWh}$ and $2.71 \mathrm{tCO}_{2}$ respectively. The obtained results show that daylight-linked control systems make a significant contribution to climate change goals with reasonable life cycle greenhouse emission values. Therefore, it is likely to propose that adapting lighting technologies is vital to improve the carbon footprint of buildings. However, this adaption must be carried out with political leadership to fight the coming climate crisis which is expected to have more destroying effects in the coming decades. In the near future, all actions to reduce/cut emissions in all sectors must be of top priority in order to limit warming to suggested temperatures for a sustainable future.

\section{References}

[1] B. M. Sanderson et al., "Community climate simulations to assess avoided impacts in 1.5 and 2 degree futures,” Earth Syst. Dyn. Discuss.; vol. 8, pp. 827-847, 2019.

[2] International Energy Agency. “Tracking Buildings,” OECD/IEA, Paris, France, 2020. [Online]. Available: https://www.iea.org, [Accesed: June 2020].

[3] M. A. ul Haq et al, "A review on lighting control technologies in commercial buildings, their performance and affecting factors,” Renewable and Sustainable Energy Reviews, vol. 33, pp. 268-279, 2014.

[4] L. Bellia et al, "Why are daylight-linked controls (DLCs) not so spread? A literature review," Building and Environment, vol. 106, pp. 301-312, 2016.

[5] A. Williams et al., "Rubinstein Lighting controls in commercial buildings," LEUKOS - J Illum Eng Soc N Am, vol. 8, pp. 161-180, 2012.

[6] D. H. W. Li et al., "An analysis of energy-efficient light fittings and lighting controls,” Appl Energy, vol. 87, pp. 558-567, 2010.

[7] T. M. Chung et al., "Office Lighting Retrofit Using Dimmable Electronic Ballasts and Occupancy Controls,” HKIE Transactions, vol. 8(3), pp. 8-15, 2001.

[8] N. Guillemin et al., "An innovative lighting controller integrated in a self-adaptive building control system,” Energy and Buildings, vol. 33(5), pp. 477-487, 2001.

[9] S. Onaygil et al., "Determination of the energy saving by daylight responsive lighting control systems with an example from İstanbul," Building and Environment, vol. 38(7), pp. 973-977 2003.

[10] M. R. Atif et al., "Energy performance of daylight-linked automatic lighting control systems in large atrium spaces: report on two field-monitored case studies," Energy and Buildings, vol. 35(5), pp. 441-461, 2003. 
[11] R. Delvaeye et al., "Analysis of energy savings of three daylight control systems in a school building by means of monitoring,” Energy and Buildings, vol. 127, pp. 969-979, 2016.

[12] M. Demirbaş et al. "Investigation of Energy Saving Performance and Other Related Parameters of a Daylighting Scenario for an Industrial Building," Light\&Engineering, vol. 25(2), pp.5155, 2017.

[13] International Energy Agency, "Daylight in buildings a source book on daylighting systems and components, A Report of IEA SHC Task 21/ECBCS Annex 29, 2000,” 2000. [Online]. Available: https://www.iea.org, [Accesed: July 2020] .

[14] C. Labuschagne et al., "Sustainable project life cycle management: the need to integrate life cycles in the manufacturing sector," Int J Project Manage, vol. 23, pp. 159-168, 2005.

[15] S. N. S. B. Bakri et al., "Life cycle assessment of magnetic and electronic ballast for 36-W fluorescent lamp,” Int J Life Cycle Assess, 15:837-841, 2010.

[16] International Energy Agency, “Countries: Turkey,” 2020. [Online]. Available: https://www.iea.org, [Accesed: July 2020].

[17] Ministry of Energy and Natural Energy Sources, "Energy Balance Sheets (2019),” 2019. [Online]. Available: https://www.eigm.gov.tr, [Accessed May 2020]. 